\title{
Criminalisation of HIV transmission- An Overview for Clinicians
}

Corresponding Author (first author):

Dr Priyanka Saigal

Department of Sexual Health and HIV at King's College Hospital

Caldecot Centre

Caldecot rd

Camberwell

London

SE5 9RS

Tel: 02032994800

E-mail: psaigal@nhs.net

Second Author:

Prof Matthew Weait

University of Portsmouth

Portsmouth

UK

Third Author:

Dr Mary Poulton

King's College Hospital

London

UK

Key Words: Ethics, Law, HIV

Word Count: 1194

[Type text] 


\section{Criminalisation of HIV transmission- An Overview for Clinicians}

The law surrounding criminal liability for HIV transmission is complex, but informing patients of potential culpability is arguably ${ }^{1}$ part of our professional duty. The purpose of this summary is to simplify and guide clinicians by explaining the legal basis for criminalising HIV transmission, defining reckless transmission, and discussing how disclosure, condoms and treatment as prevention (TasP) may impact criminal liability. Lastly, it discusses how this information can easily be conveyed to patients.

HIV criminalisation refers to the investigation, prosecution and conviction of people for transmitting, or exposing others to HIV. ${ }^{2}$ In England and Wales, only the intentional or reckless transmission of HIV and deliberate (but unsuccessful) attempts to transmit are criminalised. In Scotland, however, where the legal system differs, reckless exposure may also be criminalised ${ }^{3}$.

Most criminal offences require proof beyond reasonable doubt of three things. First, the prosecution must establish the requisite act, conduct or consequence (known as the actus reus). Second, it must prove that defendant intended the consequence or acted recklessly (known as the mens rea). Thirdly, it must disprove any valid defence that the defendant may

\footnotetext{
${ }^{1}$ Dodds, C; Weait, M; Bourne, A; Egede, S 'Keeping confidence: HIV and the criminal law from HIV service providers' perspectives ,' [2015] 8 Critical Public Health 410-426

$2{ }^{2}$ Weait, M. 2011.'The Criminalisation of HIV Exposure and Transmission: A Global Review'. Working Paper prepared for the Third Meeting of the Technical Advisory Group, Global Commission on HIV and the Law, 7-9 July, 2011, available at: https://hivlawcommission.org/wp-content/uploads/2017/06/Criminalisation-of-HIVExposure-and-Transmission.pdf

${ }^{3}$ In 2010 Mark Devereaux was prosecuted under the Scottish common law offence of reckless endangerment on four counts, although transmission had only occurred in one case. See BBC News, 'HIV man jailed for reckless sex' (25 February 2010) http://news.bbc.co.uk/1/hi/scotland/north east/8519593.stm accessed 6 March 2018
}

[Type text] 
raise. The applicable law in HIV criminalisation cases is the Offences Against the Person Act 1861, which enables prosecution of intentional transmission under s. 18 , and reckless transmission under s. 20. Deliberate attempts to infect are charged under the Criminal Attempts Act 1981.

For the purposes of the s. 20 offence, the mens rea is 'recklessness'. This is defined by the courts as "a conscious risk taking, where a person knows that some harm may arise from his conduct, but he continues to take this risk"4. Thus, for a finding of recklessness, the person would need to know or think that they had HIV, know how HIV is transmitted and fail to take adequate measures to mitigate the risk of transmission. The actus reus of the offence, is the infliction or causing of grievous bodily harm, meaning that it must be proven that the defendant is the source of the infection ${ }^{5}$. Consent to the risk of harm is a legally valid defence and for the purposes of s. 20, absolves the individual of liability. S. 18 of the Offences Against the Person Act differs, as here the mens rea is the intent to cause serious harm and in the case of HIV transmission, corresponds to the deliberate transmission of HIV. The actus reus is the same as the s. 20 offence, but there is no legally valid defence of consent ${ }^{6}$. The differences and similarities between the two offences are depicted in figure 1 . The remainder of this article focuses on reckless transmission of HIV because this is more commonly prosecuted.

The first conviction for reckless transmission of HIV in England Wales was in 2004, in $R v$ Dica ([2004] EWCA Crim 1103). Mr Dica was diagnosed with HIV in 1999. He understood how HIV

\footnotetext{
${ }^{4} R$ v G [2003] UKHL 50, [2004] 1 AC 1034

${ }^{5}$ Bernard, E., Azad, Y., Vandamme, A., Weait, M. and Geretti, A. (2007), HIV forensics: pitfalls and acceptable standards in the use of phylogenetic analysis as evidence in criminal investigations of HIV transmission-. HIV Medicine, 8: 382-387. doi:10.1111/j.1468-1293.2007.00486.x

${ }^{6} R v$ Brown [1993] 2 All ER 75
}

[Type text] 
was transmitted and subsequently had unprotected sex with two women, both of whom contracted HIV as a result. The Court found that Dica had not raped the women, or purposely set out to infect them. Rather, he had been reckless as to whether they would become infected. The subsequent case of $R v$ Konzani ([2005] EWCA Crim 706) examined whether consent to unprotected sex could be regarded as consent to the risk of HIV, therefore amounting to a legally valid defence which would have precluded Mr Konzani from being found guilty of reckless transmission. The Court felt that this would not suffice and that consent needed to be a "willing" and "conscious" decision to put oneself at risk of acquiring HIV, drawing a distinction between "running a risk on one hand and consenting to run that risk on the other"7." The Court of Appeal rejected the notion that someone can consent to the risk of HIV based on a general awareness of risk, placing the responsibility to reduce transmission on the HIV positive partner. The Court's decision in Konzani fell short of mandating HIV disclosure, but this appears to be the only means of securing the defence of consent where the court has found the prerequisite mens rea and actus reus. This is summarised in Figure 1. Some commentators have argued in favour of criminalisation, suggesting that it will or may have a positive public health impact by acting as a deterrent to those who would have otherwise behaved recklessly ${ }^{8}{ }^{9}$. However, by placing the entire burden of reducing HIV transmission on the positive partner, the approach of the courts is inconsistent with public health initiatives aimed at reducing HIV transmission, such as PreP (pre-exposure prophylaxis), which promote and enable individual responsibility within the HIV negative population.

\footnotetext{
${ }^{7} R v$ Konzani [2005] EWCA Crim 7063

${ }^{8}$ Schuklenk U, 'Should we use the criminal law to punish HIV transmission,' [2009] 4 International Journal of Law in Context 227 p 227,228

${ }^{9}$ Spencer J, 'Liability for reckless infection- part 2,' [2004] 154 NLJ 448 p 451

[Type text]
} 
An individual can also avoid liability for reckless transmission if they have taken steps to mitigate the risk of transmission. Although not specifically tested in the courts, condom use and treatment as prevention (TasP) are significant. The importance here is the individual's actual beliefs around transmission; if he believes that once the viral load is undetectable that he cannot transmit HIV, or that condoms make the risk of transmission negligible, then in the unlikely event of transmission occurring, the mens rea of recklessness is unlikely to be found. ${ }^{10}$

Therefore, when it comes to discussing criminal liability with patients, the message easily aligns with the public health agenda. We may safely state that a) people have been convicted of transmitting HIV in England and Wales and of intentionally attempting to transmit; and b), that in order to minimise the risk of being found criminally liable we recommend consistent use of condoms or TasP. If such steps are not taken then disclosing one's HIV status to partners will serve to protect them against criminal liability where transmission occurs, if disclosure results in consent to the risk of HIV acquisition.

\footnotetext{
${ }^{10}$ https://www.cps.gov.uk/legal-guidance/intentional-or-reckless-sexual-transmission-infection [Type text]
} 